\title{
Local paleo-tsunami size evaluation using numerical modeling for boulder transport at Ishigaki Island, Japan
}

\author{
1 Department of Civil and Environmental Engineering, Graduate School of Engineering, Tohoku University, 468-1-305 Aza-Aoba, Aramaki, \\ Aoba-ku, Sendai 980-0845, Japan. E-mail: Hisamatsu@tsunami2.civil.tohoku.ac.jp \\ 2 International Research Institute of Disaster Science (IRIDeS), Tohoku University, 468-1 Aza-Aoba, Aramaki, Aoba-ku, Sendai 980-0845, \\ Japan
}

In this study, we simulated the transport of a large coralline boulder on southern Ishigaki Island of the Sakishima Islands, Japan, to evaluate local paleotsunami size in comparison to a well-known historical event (the 1771 Meiwa tsunami). According to the geological evidence, the boulder was deposited at $10 \mathrm{~m}$ elevation by two paleo-tsunami events. We assumed two types of fault models and eight dislocations for each fault. Then we investigated whether there are any combinations of the fault models that can satisfy the movement of the boulder from its presumed initial position to the present position by two tsunamis. Results show that several combinations of tsunami source models can satisfy the geological constraints. Our results revealed that at least one tsunami event during the prehistoric age was equivalent to or even larger than the 1771 tsunami in terms of the flow depth at the southeastern coast of the Ishigaki Island. Although the accuracy of this method depends strongly on the available geological evidence, we infer that the numerical modeling for boulder transport will have great value for evaluation of the local tsunami size, which is important for local tsunami risk assessment.

\section{Introduction}

For better future tsunami risk assessment, it is extremely important to elucidate the local tsunami history in terms of parameters such as the size and recurrence interval of tsunamis that occurred during historical and prehistoric ages. Historical and geological records are useful to estimate the inundation areas and sources of paleo-tsunamis (e.g., Sawai et al., 2012). Many works have been done to estimate the size and recurrence interval of paleo-tsunamis based on such records (e.g., Atwater et al., 2005; Cisternas et al., 2005; Jankaew et al., 2008). Numerical modeling based on geological records is also useful to improve estimation of the size of local tsunamis as well as the source model (e.g., Koshimura et al., 2002; Nanayama et al., 2003). However, many of these works used sandy tsunami deposits because sandy tsunami deposits are useful to estimate minimum tsunami inundation areas (e.g., MacInnes et al., 2009; Morton et al., 2007). Although various sizes of tsunami deposits from mud to boulders have been reported (e.g., Clague et al., 2000; Dawson and Shi, 2000; Gelfenbaum and Jaffe, 2003; Goff et al., 2010, 2012; Goto et al., 2010a; Sheffers, 2008; Sugawara et al., 2012; Yamada et al., in press), very few studies have used deposits other than sandy ones to estimate the paleo-tsunami size.

Tsunami boulders have recently been recognized as important geological evidence of paleo-tsunamis (Etienne et al., 2011). These boulders are deposited along coastal areas throughout the world (Goto et al., 2010a). The size and source model of paleo-tsunamis has been assessed based on boulder deposits (e.g., Frohlich et al., 2009). For example, Tonga has one of the largest deposited boulders in the world, estimated as weighing more than 1600 tons (Frohlich et al., 2009). Using numerical modeling with an equation reported by Nott and Bryant (2003), Frohlich et al. (2009) calculated the required tsunami height sufficient to cast this boulder ashore to its present position. They found that volcanic flank collapse or submarine slumps are the plausible tsunami sources providing sufficient tsunami height. However, the equation reported by Nott and Bryant (2003) calculates the minimum current velocity to move the boulder. For that reason, it is probable that the estimated size and source model are markedly underestimated. To estimate the size and source model of paleotsunamis better using boulder deposits, forward modeling of boulder transport by the tsunami (e.g., Imamura et al., 2008; Nandasena et al., 2013; Sugawara et al., 2014) may be more appropriate, because the forward modeling can evaluate whether large boulders can be moved from the initial position to the present position by the arbitrary size of the tsunami.

In the Sakishima Islands at the southeastern end of Japan (Fig. 1), numerous coralline and reef boulders are believed to have been deposited by paleo-tsunamis (Goto et al., 2010a). Araoka et al. (2013) conducted radiocarbon dating of 92 Porites tsunami boulders and reported that eight tsunamis would have struck the Sakishima Islands during the last approximately 2400 years $(250 \pm 100$ B.C., A.D. $200 \pm 100$, A.D. $550 \pm 100$, A.D. $800 \pm 100$, A.D. $1100 \pm 100$, A.D. $1400 \pm 100$, A.D. $1600 \pm 100$, A.D. $1800 \pm 100$ ). The latter two events are probably consistent with historically recorded events occurring in 1625 and 1771 (Fig. 2, Araoka et al., 2013). Among them, the 1771 tsunami, the so-called the Meiwa tsunami, is remarkable because 


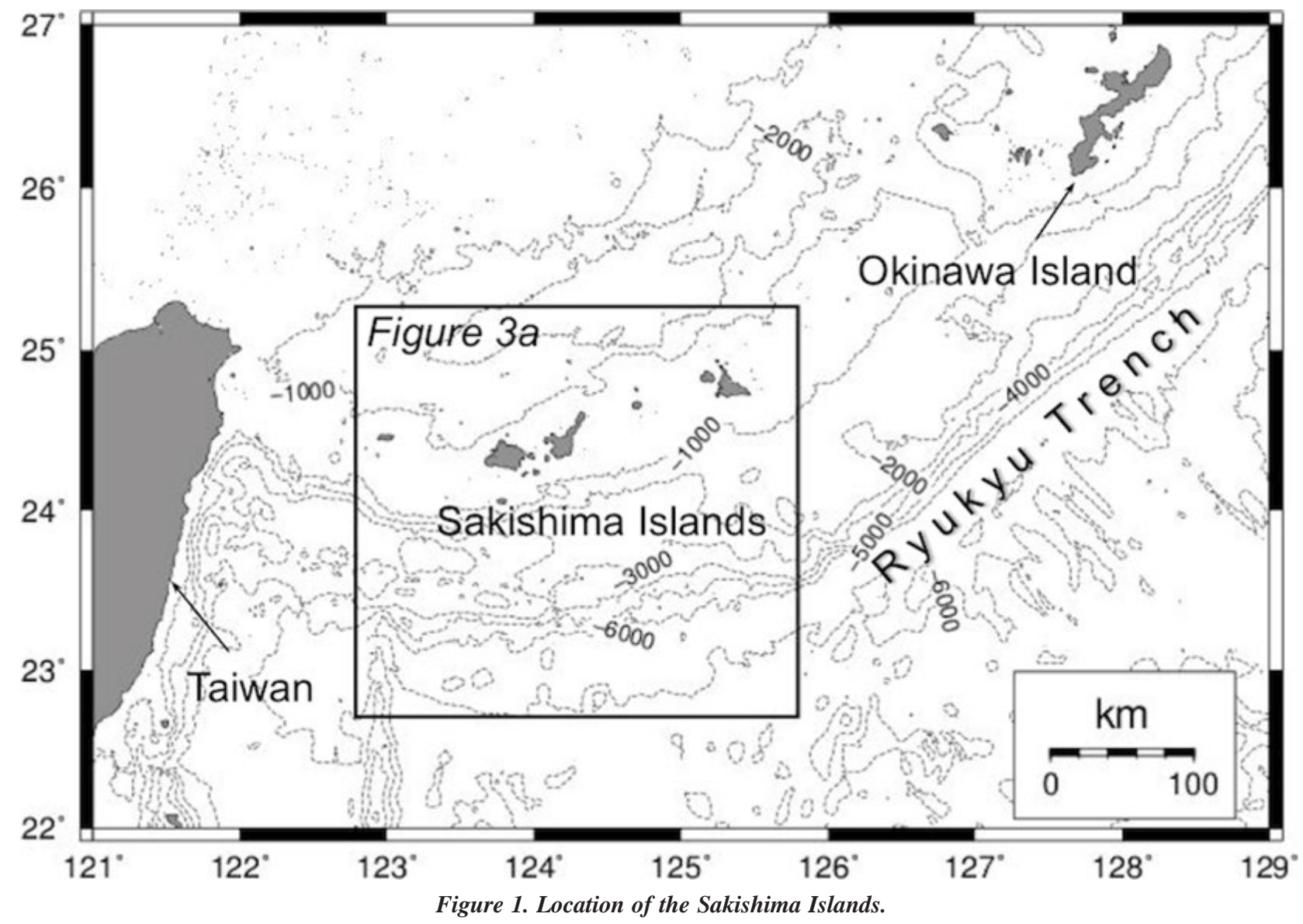

great amounts of historical and geological evidence, including tsunami boulders, are available (e.g., Goto et al., 2010a; Kawana and Nakata, 1994). Nevertheless, the tsunami source model of the 1771 event has remained controversial: a fault plus a submarine landslide (Imamura et al., 2001, 2008; Miyazawa et al., 2012) and a tsunami earthquake assuming a thrust fault along the plate boundary (Nakamura, 2009) have been proposed as possible causes.

The potential usefulness of tsunami boulders to improve estimation of the size and source model of the 1771 tsunami as well as the past events before 1771 was reported by Imamura et al. (2008). However, tsunami boulders have never been used to evaluate paleotsunami size. Therefore, it remains uncertain whether large tsunami(s) that are equivalent to or even larger than the 1771 event occurred repeatedly before 1771 or not. Nevertheless, this presents an extremely important question for local tsunami risk assessment.

This study was conducted to explore methods to use tsunami boulders to improve paleo-tsunami size estimation based on the forward model of boulder transport. To achieve this objective and to simplify the discussion, we examine only a single large coralline boulder deposited on the Ishigaki Island in the Sakishima Islands (detailed information about the boulder will be described in Geological setting). Using this boulder, we investigated local paleo-tsunami sizes at southeastern coast of the Ishigaki Island during the past 2400 years. Results suggest that at least one large tsunami equivalent to the 1771 event occurred before 1771 .

\section{Geological setting}

The Ishigaki Island, located approximately $400 \mathrm{~km}$ southwest from the Okinawa Island, is surrounded by fringing reefs and the maximum distance between the coastline and reef edge is about $1.5 \mathrm{~km}$ (Goto et al., 2010a). The tide is semidiurnal, with a maximal range at spring tide of $2.0 \mathrm{~m}$ and mean low tide level that is $1.0 \mathrm{~m}$ below mean sea level (Iryu et al., 1995). The Ryukyu trench lies about $100 \mathrm{~km}$ south of the Ishigaki Island. The relative plate motion is $67 \mathrm{~mm} / \mathrm{yr}$ (Rhea et al., 2010).

Goto et al. (2010a) investigated the distribution of boulders in the Ryukyu Islands. They reported that boulders transported by typhoon-generated storm wave were distributed only on the reef crest (within approximately $300 \mathrm{~m}$ inland from reef edge), although tsunami-transported boulders reached the beach and further inland after crossing over the $1.5 \mathrm{~km}$ reef flat.

The largest coralline boulder on the Ishigaki Island, the so-called "Tsunami ufu-ishi" boulder (Fig. 4c, hereinafter designated as the TU boulder), was deposited approximately $100 \mathrm{~m}$ inland from the present shoreline (approximately $10 \mathrm{~m}$ a.s.l.) at the southern coast of the island (Figs. $4 \mathrm{a}$ and $4 \mathrm{~b}$ ). The boulder dimensions are approximately $12.4 \times 10.8 \times 5.9 \mathrm{~m}$. It weighs more than 500 tons, as inferred from its material and ellipsoidal shape (coral density was $1.62 \mathrm{ton} / \mathrm{m}^{3}$ ). The boulder porosity was assumed as $20 \%$, based on Kawana (2008). This study used this boulder for the numerical modeling because the boulder is the largest prehistoric tsunami boulder in the Sakishima Islands whose depositional age and rotation history was estimated from the radiocarbon dating (Kawana and Nakata, 1994) and paleomagnetic analysis (Sato et al., 2013). Moreover, the original location can be estimated from the coral assemblage (Kawana et al., 1987) as described below. Therefore, the boulder is adequate to evaluate sizes of paleo-tsunamis in the Ishigaki Island. 


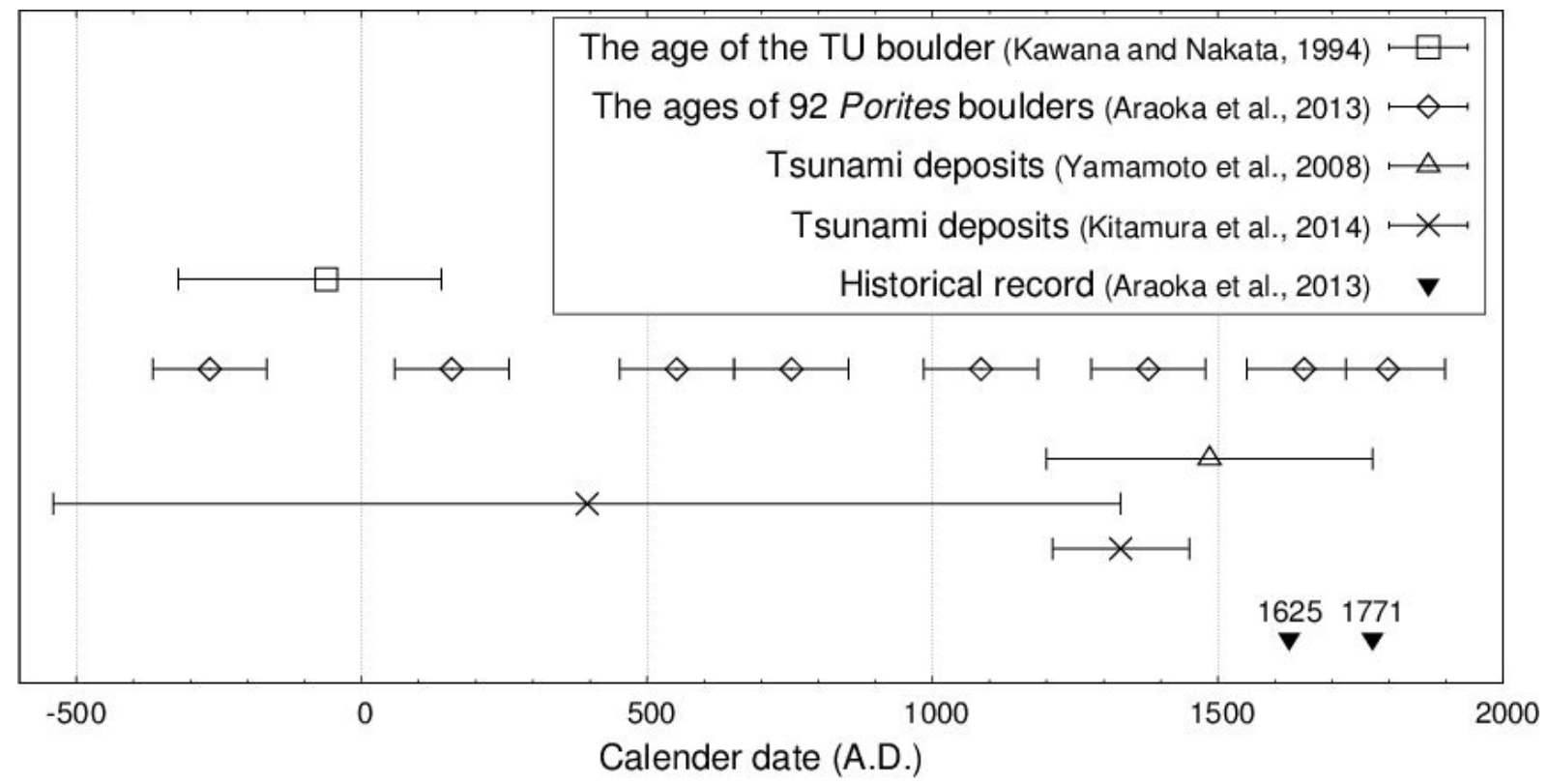

Figure 2. Tsunami occurrence according to the radiocarbon age of the TU boulder (Tsunami ufu-ishi)(Kawana and Nakata, 1994), the ages of 92 Porites boulders in the Sakishima Islands (Araoka et al., 2013), historical records (Araoka et al., 2013), and the ages of tsunami deposits (Yamamoto et al. 2008 and Kitamura et al., 2014).

The original position of the boulder is estimated as shallower than $10 \mathrm{~m}$ water depth of the reef slope, based on coral assemblages (Favia, Favites, Acropora, Goniastrea, Platygra) (Kawana et al., 1987). Moreover, considering the boulder height (approximately 6 $\mathrm{m}$ ) and tidal range $\pm 1 \mathrm{~m}$, the boulder is expected to have been located in deeper than $7 \mathrm{~m}$ of water depth because corals cannot grow above the lowest tide level. The radiocarbon age of a coral taken at the youngest part of the boulder showed 1980 \pm 80 yrBP (Kawana and Nakata, 1994). Consequently, it is likely that the boulder emerged above sea level from the water during 321 B.C.-A.D. 140 (2б) (see Appendix 1).

Kawana and Nakata (1994) and Goto et al. (2010a) proposed that the TU boulder was likely to have been deposited by the paleotsunami at around 321 B.C.-A.D. 140 because (1) it should have been relocated from somewhere by the wave when the tide level was, at that time, almost equal to the present level (Kawana, 2006). Therefore, the boulder presence at $10 \mathrm{~m}$ elevation cannot be explained by the sea level change. (2) The distance from the nearest reef edge is about $450 \mathrm{~m}$, which is far greater than the transport limit of storm wave boulders as estimated by Goto et al. (2010a). In fact, Goto et al. (2010a) reported that the boulder was not moved from its present position even by the 1771 event because no historical description exists of movement of the boulder. Movement of much smaller boulders near the TU boulder was described, which also suggests that the TU boulder was deposited in its present location by a large tsunami before 1771 .

Rotation history of the TU boulder is also well studied (Sato et al., 2013). Boulders originally grew as corals on the reef before the tsunami. The corals acquired depositional remanent magnetization parallel to Earth's current magnetic field as natural remanent magnetization, and after the corals were transported by tsunami, new remanence was superimposed as viscous remanent magnetization parallel to Earth's current magnetic field (Sato et al., 2014). Vector component changes can be seen in vector plots for successive thermal demagnetization steps, if the boulder had been rotated (Sato et al.,
2014). Based on this idea, Sato et al. (2013) reported that the TU boulder was rotated twice in the past by two paleo-tsunamis.

Alternatively, it is possible that the boulder was rotated once by a typhoon-generated storm wave at the source on the reef slope and then displaced to the present position by one large tsunami. However, this boulder is extremely heavy (approximately 500 tons) and it is far heavier than the known storm wave boulders at Ryukyu Islands $(<200$ tons, Goto et al., 2013). Moreover, if the boulder can be rotated by storm waves, it should have been rotated many times because many large typhoons attack the Ishigaki Island every year. Considering that the boulder was rotated only twice during the last 2000 years (Sato et al., 2013), it is unlikely that the boulder was rotated by such high frequency typhoon-generated storm wave and we prefer the interpretation proposed by Sato et al. (2013) that it was rotated by two large tsunami events.

Yamamoto et al. (2008) reported a sandy tsunami deposit on the eastern coast of the Ishigaki Island that was deposited after A.D. 1200 but before A.D. 1771 (Fig. 2). Kitamura et al. (2014) reported two possible tsunami deposits that were probably deposited by the tsunami in 540 B.C.-A.D. 1330 and A.D. 1210-1450 at an eastern coastal area of the Ishigaki Island (Fig. 2). The former tsunami event might be of comparable age to the emergence of the TU boulder.

In summary, the geological evidence presented above suggests that (1) the TU boulder emerged above the lowest sea level by the tsunami at around 321 B.C.-A.D. 140 and that (2) it was moved (or rotated) again by the tsunami occurring after that event but before 1771. It reached its present position, and (3) it remained unmoved by the 1771 Meiwa tsunami. These three geological implications are used as constraint conditions for our numerical modeling.

\section{Numerical method}

In this study, we assumed that the TU boulder was moved twice by two tsunamis based on Sato et al. (2013). We calculated the boulder transport by the first tsunami and estimated its stop position. Then, 
the final stop position after the first tsunami was used as the initial position of the second tsunami event. If the boulder stopped within the $50 \mathrm{~m}$ radius circle, we infer that the modeling result satisfies the constraint conditions. Detail numerical methods and constraint conditions are explained below.

\section{Numerical calculation for boulder transport by tsunami}

Numerical modeling for the tsunami inundation fundamentally follows that of Miyazawa et al. (2012). A nested grid system constructed by Miyazawa et al. (2012) was used across a wide area (regions 1 and 2) to the coast of each island (region 3). Spatial grid sizes of each region are, $300 \mathrm{~m}$ for region 1 (Fig. 3a), $100 \mathrm{~m}$ for region 2 (Fig. 3a) and $50 \mathrm{~m}$ for region 3 (Fig. 3b), respectively (Miyazawa et al., 2012). We also added region 4 with a $10 \mathrm{~m}$ grid (Fig. 3c) for detailed modeling of boulder transport by the tsunami. Our preliminary modeling revealed no effect of the third and later waves for the movement of the TU boulder. Therefore, we calculated up to $30 \mathrm{~min}$ after the tsunami generation to simulate the boulder movement by the end of the second backwash.

The Boulder Transport by Tsunami model (hereinafter the BTT model, see Appendix 2 for the method) developed by Imamura et al. (2008) was used to calculate the boulder movement by the tsunami in region 4 . The model validity was well confirmed by several examples such as the 2004 Indian Ocean tsunami (Goto et al., 2010b) and the 1771 Meiwa tsunami (Imamura et al., 2008).

\section{Source models for evaluating paleo-tsunami size at the $T U$ boulder}

As stated in Geological setting, the TU boulder was likely to have been moved to its present position by two tsunami events before 1771 (Sato et al., 2013). Then, the question is whether the sizes of these two paleo-tsunamis were equivalent to or greater than that of the 1771 event. To explore the answer to this question, we evaluate the sizes of two paleo-tsunamis before 1771 using the BTT model. However, to adopt the BTT model, the tsunami source should be assumed, but geological evidence of prehistoric tsunamis is insufficient to evaluate the tsunami source. Therefore, we assume the source model of the 1771 event, which is well estimated, as the basis of the source of paleo-tsunamis and discuss whether the local tsunami heights of paleo-tsunamis were larger than the 1771 event or not.

Two tsunami source models for the 1771 event were used for our analysis (Table 1). Nakamura (2009) proposed a Mw=8.0 inter-plate earthquake along the Ryukyu trench (hereinafter called the NK model), whereas Miyazawa et al. (2012) proposed a combination of a Mw=8.2 intra-plate earthquake and submarine landslide, the latter of which is imitated by a fault model (hereinafter called the MY model) (Fig.
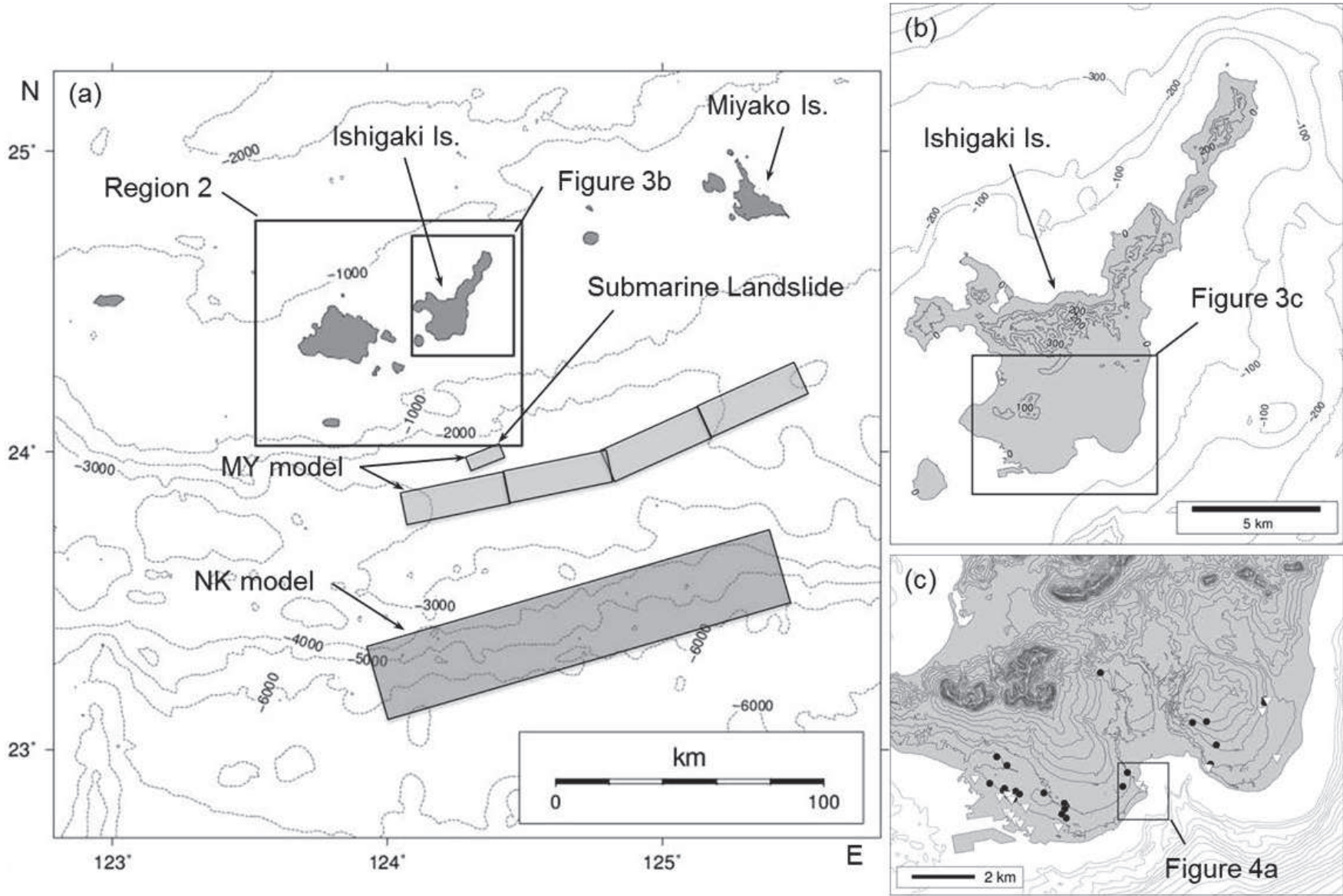

Figure 3. Regions 1-4 for numerical calculations. (a) Region 1 for numerical calculation. NK and MY model in the figure respectivelyshow the 1771 Meiwa tsunami model proposed by Nakamura (2009) and Miyazawa (personal communication). (b) Region 3 for numerical calculation. (c) Region 4 for numerical calculation and 45 instances of historical evidence related to the Meiwa tsunami. White triangles show sites inundated by the Meiwa tsunami. Black dots show non-inundated sites. 
Table 1. Fault parameters of tsunami source models for the 1771 Meiwa tsunami. The NK model was proposed by Nakamura (2009). The MY model was proposed by Miyazawa (personal communication) and we slightly revised it from Miyazawa et al. (2012).

\begin{tabular}{ccccccccccc}
\hline Model & $\begin{array}{c}\text { Tsunami } \\
\text { source }\end{array}$ & $\begin{array}{c}\text { Latitute } \\
(\mathrm{deg})\end{array}$ & $\begin{array}{c}\text { Longitude } \\
(\mathrm{deg})\end{array}$ & $\begin{array}{c}\text { Depth } \\
(\mathrm{km})\end{array}$ & $\begin{array}{c}\text { Length } \\
(\mathrm{km})\end{array}$ & $\begin{array}{c}\text { Width } \\
(\mathrm{km})\end{array}$ & $\begin{array}{c}\text { Dislocation } \\
(\mathrm{m})\end{array}$ & $\begin{array}{c}\text { Strike } \\
(\mathrm{deg})\end{array}$ & $\begin{array}{c}\text { Dip } \\
(\mathrm{deg})\end{array}$ & $\begin{array}{c}\text { Rake } \\
(\mathrm{deg})\end{array}$ \\
\hline $\begin{array}{l}\text { NK model } \\
(\mathrm{Mw}=8.0)\end{array}$ & Fault 1 & 23.5000 & 125.4500 & 5 & 150 & 30 & 16 & 255 & 12 & 90 \\
\hline & Fault 1 & 24.2018 & 125.5184 & 5 & 41 & 35 & 14 & 245 & 70 & 90 \\
& Fault 2 & 24.0526 & 125.1497 & 5 & 40 & 35 & 14 & 246 & 70 & 90 \\
MY model & Fault 3 & 23.9100 & 124.8000 & 5 & 35 & 35 & 13 & 259 & 70 & 90 \\
$(\mathrm{Mw}=8.2)$ & Fault 4 & 23.8421 & 124.4576 & 5 & 36 & 35 & 14 & 261 & 70 & 90 \\
& Landslide & 24.0036 & 124.2640 & 0.1 & 12 & 8 & 90 & 76 & 70 & 90 \\
\hline
\end{tabular}

3a). These models are well consistent with the measured run-up heights at many places in the Sakishima Islands. However, both models underestimated the tsunami run-up heights in the southern part of the Ishigaki Island (Miyazawa et al., 2012), where the maximum run-up height (approximately $30 \mathrm{~m}$ ) was recorded (Goto et al., 2010a). Therefore, we first improve the NK and MY models by changing the dislocation of the fault in case of the NK model, and the dislocation of landslide-imitated fault in case of MY model to satisfy the run-up heights along the southeastern part of the Ishigaki Island based on 45 instances of historical evidence that indicate inundated (19 sites) and non-inundated (26 sites) area by the 1771 tsunami (Fig. 3c). It is noteworthy that the model estimated for this study is not necessarily the actual model of the 1771 event because we consider only the historical records along the southeast coast of the Ishigaki Island and thus this fault model may not fit to the inundation area or run-up heights at other islands. In this sense, we do not regard this model as the source model of the 1771 event but, rather, regard it as the benchmark tsunami source model that satisfies the inundation area and run-up height specifically at the southeastern coast of the Ishigaki Island.

It is important to note that many combinations of tsunami source models may satisfy the constraint conditions in Geological setting. Moreover, it is uncertain whether large submarine landslides were repeatedly generated at the same location. Considering the paleotsunami traces are very scarce, it is not realistic to explore the source model of paleo-tsunamis. Our main objective is to find whether there were any paleo-tsunamis that were equivalent or larger size than the 1771 event in terms of the flow depth at the southeast coast of the Ishigaki Island. For this particular objective, we limited the modeling cases. We changed the dislocation of the fault of NK model and the dislocation of landslide-imitated fault in the case of the MY model (Table 2), respectively, to generate tsunamis with flow depths smaller or larger than the benchmark tsunami at the TU boulder position. We changed only the dislocation of the landslide-imitated fault in case of the MY model because the landslide-imitated fault may generate a tsunami with high amplitude but short wave length, which may be very different from the tsunami generated by the usual fault model (low amplitude and long wavelength). On the other hand, we did not change the slip amount of the fault in the MY model because the effect of the slip amount of the fault model is probably similar to that of the NK model and thus it is not necessary to change this in the MY model. Eight models with different fault dislocations were assumed for the NK model and MY model, respectively, to make the maximum flow depths at the present TU boulder position $1-8 \mathrm{~m}$ in every $1 \mathrm{~m}$ interval (within $0.2 \mathrm{~m}$ error). Based on this assumption, the relative sizes of paleo-tsunamis can be evaluated in comparison with the flow depth of the benchmark tsunami at the present TU boulder position.

\section{Initial setting of the $T U$ boulder and constraint conditions}

Because the exact initial position of the TU boulder is uncertain, we set 100 boulders in the area at $20 \mathrm{~m}$ intervals in 7-10 $\mathrm{m}$ water depth along the reef slope (Figs. $4 \mathrm{a}$ and $4 \mathrm{~b}$ ) based on the geological evidence (see Geological setting). Interaction among boulders (e.g. collision) and wave reflection by the boulders were not considered. We assumed that the boulder had already been detached from the reef before the tsunami struck. Although the validity of this assumption cannot be confirmed, it is likely because severe typhoons frequently strike the reef, as frequently as every year, and many fragments of reef rocks remain on the slope of the present reef. The average distance between the present and initial positions of the TU boulder was approximately $970 \mathrm{~m}$ (the shortest distance was $826 \mathrm{~m}$ and the longest distance was $1104 \mathrm{~m}$ ). The vertical elevation distance is approximately $19.0 \mathrm{~m}$, on average (Figs. 4a and 4b).

Considering the uncertainties and errors of the model, we evaluated the size of tsunamis according to whether the boulder reaches a circle with $50 \mathrm{~m}$ (100 m diameter) radius from the TU

Table 2. Fault parameters of tsunami source models for evaluating the paleo-tsunami size. Fault dislocation of MY model is the dislocation of landslide-imitated fault.

\begin{tabular}{ccc}
\hline Model & $\begin{array}{c}\text { Fault } \\
\text { dislocation } \\
(\mathrm{m})\end{array}$ & $\begin{array}{c}\text { Maximum flow depth at the } \\
\text { TU boulder present position } \\
(\mathrm{m})\end{array}$ \\
\hline NK1 & 16.0 & 1.00 \\
NK2 & 19.0 & 1.98 \\
NK3 & 22.0 & 2.98 \\
NK4 & 23.5 & 4.08 \\
NK5 & 25.0 & 5.14 \\
NK6 & 26.5 & 5.96 \\
NK7 & 28.5 & 7.02 \\
NK8 & 31.0 & 8.06 \\
MY1 & 35.0 & 0.81 \\
MY2 & 60.0 & 2.18 \\
MY3 & 90.0 & 3.15 \\
MY4 & 120 & 4.10 \\
MY5 & 150 & 5.06 \\
MY6 & 180 & 5.93 \\
MY7 & 240 & 7.02 \\
MY8 & 300 & 7.98 \\
\hline & &
\end{tabular}




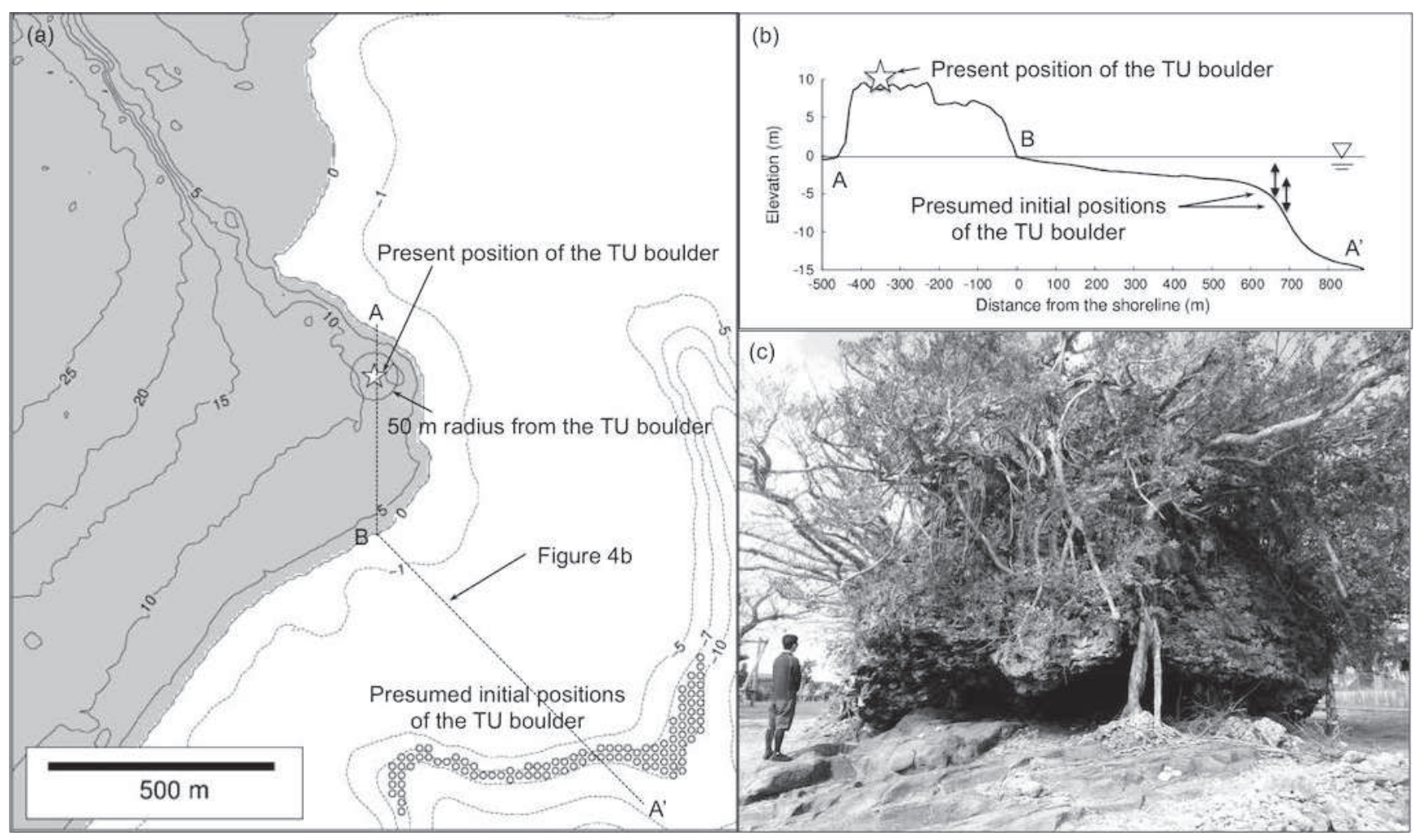

Figure 4. (a) The present position and the presumed initial positions of the TU boulder (Tsunami ufu-ishi) and their surrounding bathymetry. (b) Transect A-A'. (c) Picture of the TU boulder.

boulder's present position (Fig. 4a), which is equivalent to a $2 \mathrm{~m}$ difference in elevation. The $100 \mathrm{~m}$ distance is approximately $10 \%$ of the average distance from the TU boulder initial and present positions. Petroff et al. (2001) reported an error of approximately $20 \%$ of the final stop position of a boulder, even in the case of a well-controlled water tank experiment. Our assumption is stricter than that used for the results reported by Petroff et al. (2001).

\section{Results}

\section{Tsunami propagation and inundation}

The first wave of the tsunami reached the southern part of the Ishigaki Island at approximately 15 and 10 min respectively for the NK and MY models (Figs. 5c and 5e). In both cases, the wave trough reached the coast first. Then the wave crest marked the highest runup and the largest inundation (Fig. 5). For example, for the NK6 model, the first wave reached the initial position of the TU boulder about 16 min after the tsunami generation (Fig. 6a) and the maximum water elevation was recorded about 2 min later (Fig. 6c). After the maximum inundation, the wave direction changed 45-90 deg because of wave reflection by the steep slope (Fig. 6c). The backwash started about 2 min later (Fig. 6d). Those changes of current direction seemed to have affected the boulder movement direction.

Among the modeling cases, we first evaluate the tsunami source model, which was determined to specifically satisfy the inundation area and run-up heights of the 1771 event at southeastern coast of the Ishigaki Island, to determine the benchmark tsunami (Table 3). The inundation area increased with increasing dislocation of the fault in the NK model, and with increasing dislocation of landslide-imitated
Table 3. Numerical results for reproducibility of the 45 instances of historical evidence of the Meiwa tsunami, with inundated/non-inundated number, rate and inundation area in region 4 of each model.

\begin{tabular}{|c|c|c|c|c|c|}
\hline \multirow{3}{*}{$\begin{array}{l}\text { Historical } \\
\text { record }\end{array}$} & \multicolumn{3}{|c|}{ Number } & & \multirow[b]{5}{*}{$\begin{array}{c}\text { Inundation area } \\
\text { in region } 4 \\
\left(\mathrm{~km}^{2}\right)\end{array}$} \\
\hline & $\begin{array}{l}\text { Inundated } \\
\text { sites }\end{array}$ & $\begin{array}{l}\text { Non- } \\
\text { inundated } \\
\text { sites }\end{array}$ & Total & & \\
\hline & 19 & 26 & 45 & & \\
\hline & \multicolumn{4}{|c|}{ Reproducibility } & \\
\hline Model & $\begin{array}{l}\text { Inundated } \\
\text { sites }\end{array}$ & $\begin{array}{l}\text { Non- } \\
\text { inundated } \\
\text { sites }\end{array}$ & Total & $\begin{array}{l}\text { Rate } \\
(\%)\end{array}$ & \\
\hline NK1 & $9 / 19$ & $26 / 26$ & $35 / 45$ & 77.8 & 13.7 \\
\hline NK2 & $11 / 19$ & $26 / 26$ & $37 / 45$ & 82.2 & 16.5 \\
\hline NK3 & $12 / 19$ & $26 / 26$ & $38 / 45$ & 84.4 & 18.6 \\
\hline NK4 & $14 / 19$ & $25 / 26$ & $39 / 45$ & 86.7 & 19.5 \\
\hline NK5 & $14 / 19$ & $23 / 26$ & $37 / 45$ & 82.2 & 20.4 \\
\hline NK6 & $14 / 19$ & $23 / 26$ & $37 / 45$ & 82.2 & 21.4 \\
\hline NK7 & $15 / 19$ & $20 / 26$ & $35 / 45$ & 77.8 & 22.9 \\
\hline NK8 & $16 / 19$ & $19 / 26$ & $35 / 45$ & 77.8 & 24.6 \\
\hline MY1 & $8 / 19$ & $26 / 26$ & $34 / 45$ & 75.6 & 11.7 \\
\hline MY2 & $10 / 19$ & $26 / 26$ & $36 / 45$ & 80.0 & 14.1 \\
\hline MY3 & $10 / 19$ & $26 / 26$ & $36 / 45$ & 80.0 & 16.6 \\
\hline MY4 & $12 / 19$ & $25 / 26$ & $37 / 45$ & 82.2 & 18.4 \\
\hline MY5 & $14 / 19$ & $23 / 26$ & $37 / 45$ & 82.2 & 20.2 \\
\hline MY6 & $14 / 19$ & $21 / 26$ & $35 / 45$ & 77.8 & 22.1 \\
\hline MY7 & $17 / 19$ & $15 / 26$ & $32 / 45$ & 71.1 & 25.7 \\
\hline MY8 & $17 / 19$ & $12 / 19$ & $29 / 45$ & 64.4 & 28.9 \\
\hline
\end{tabular}




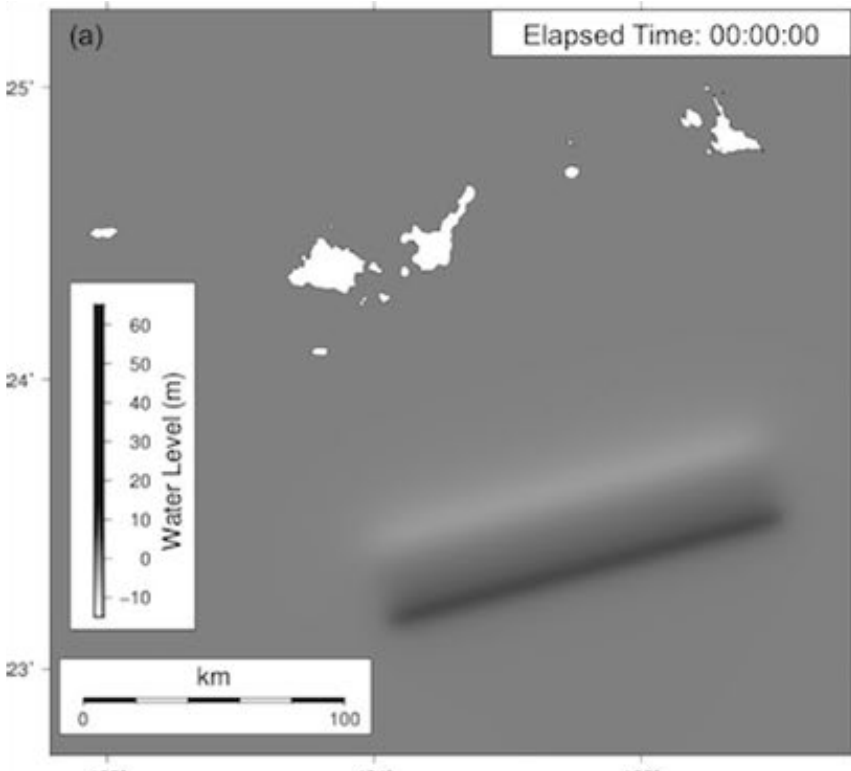

$123^{\circ}$

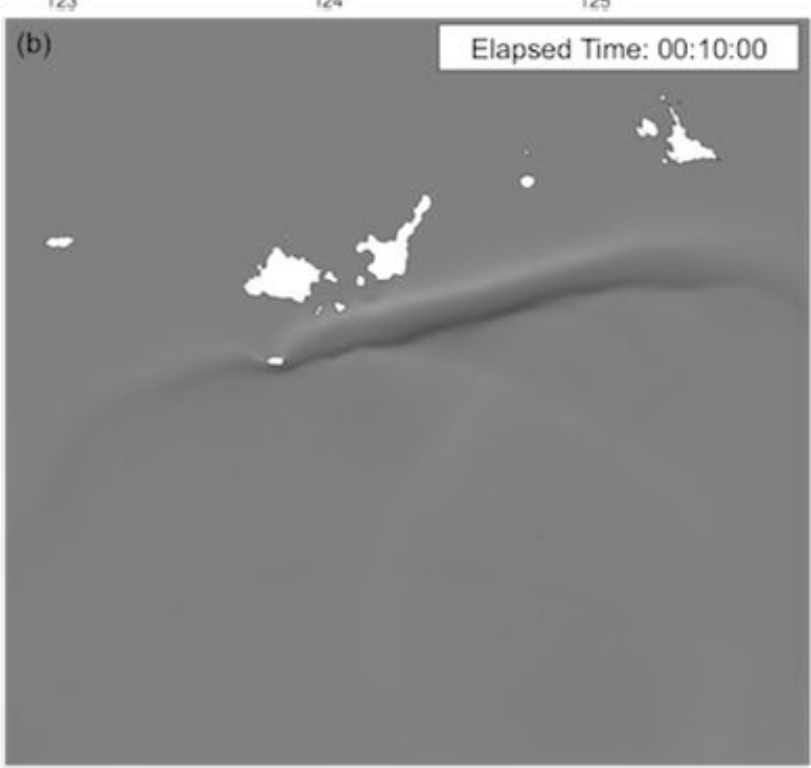

(c)

Elapsed Time: 00:15:00

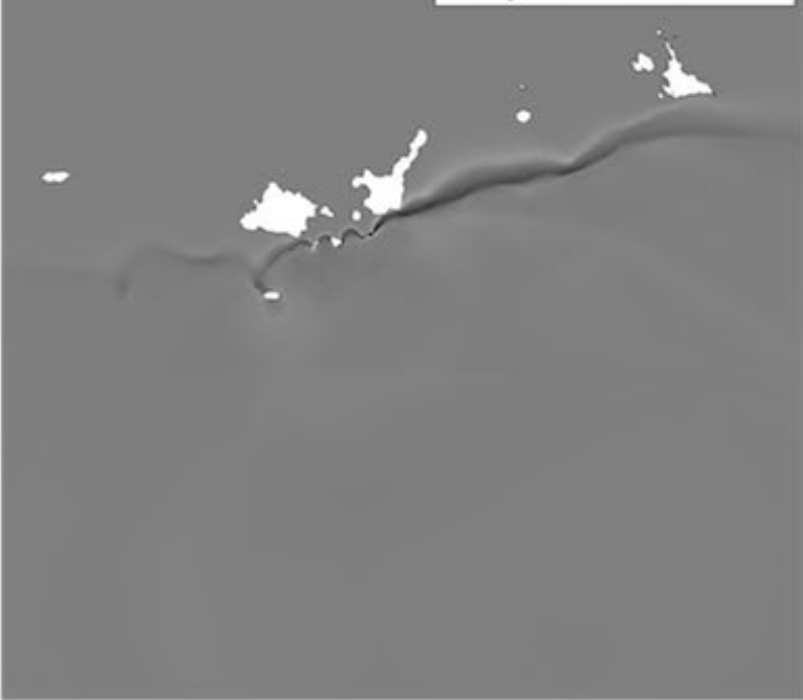

(d)

$25^{*}$

Elapsed Time: 00:00:00

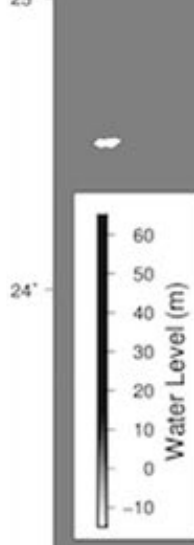

$23^{\circ}$

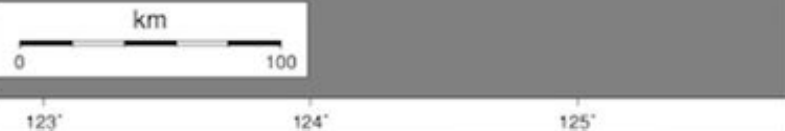

(e)

Elapsed Time: 00:10:00
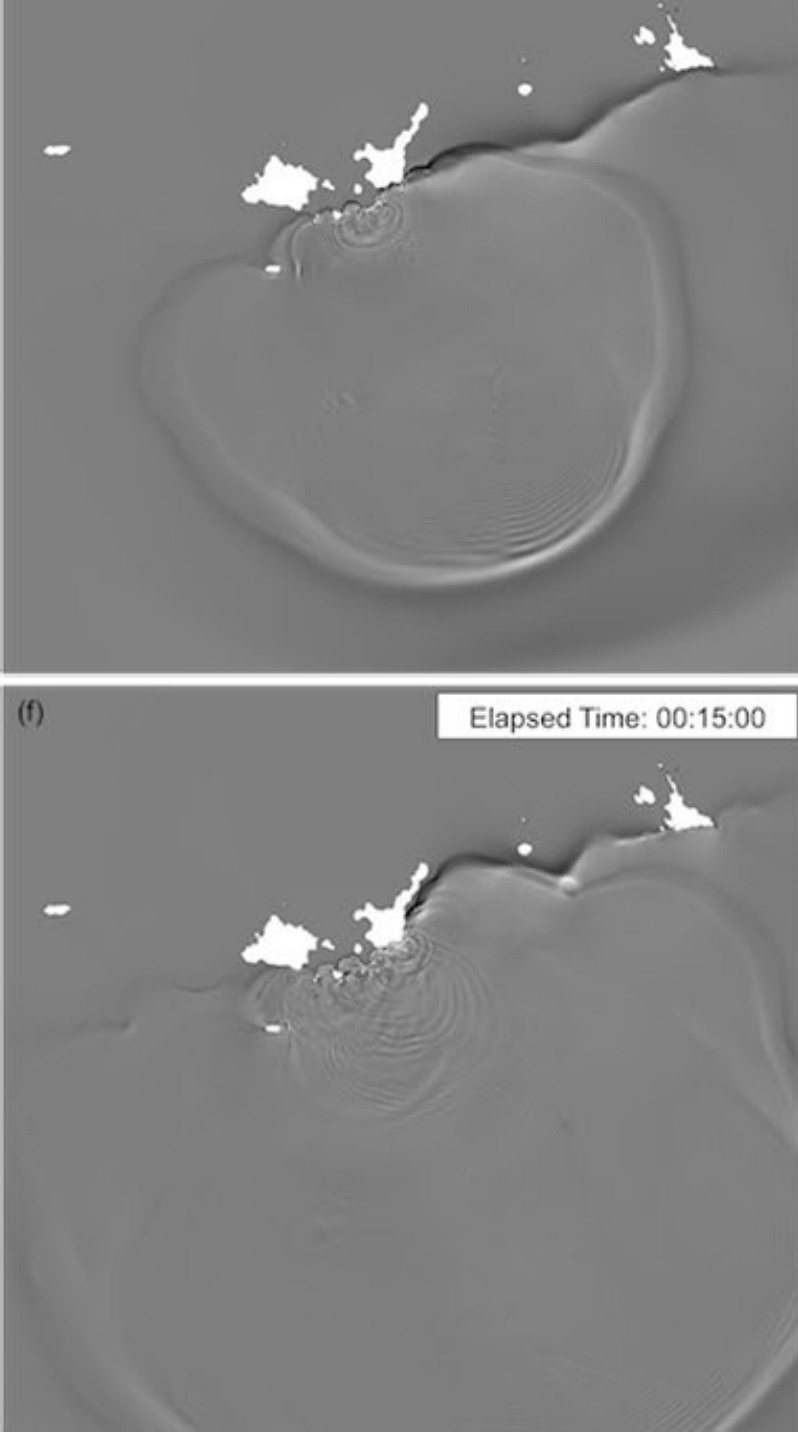

Figure 5. Snap-shots of numerical results for propagation of the 1771 Meiwa tsunami models proposed by Nakamura (2009) (left) and by Miyazawa (personal communication) (right). The images show the deformation, 10 and 15 minutes after the deformation. 


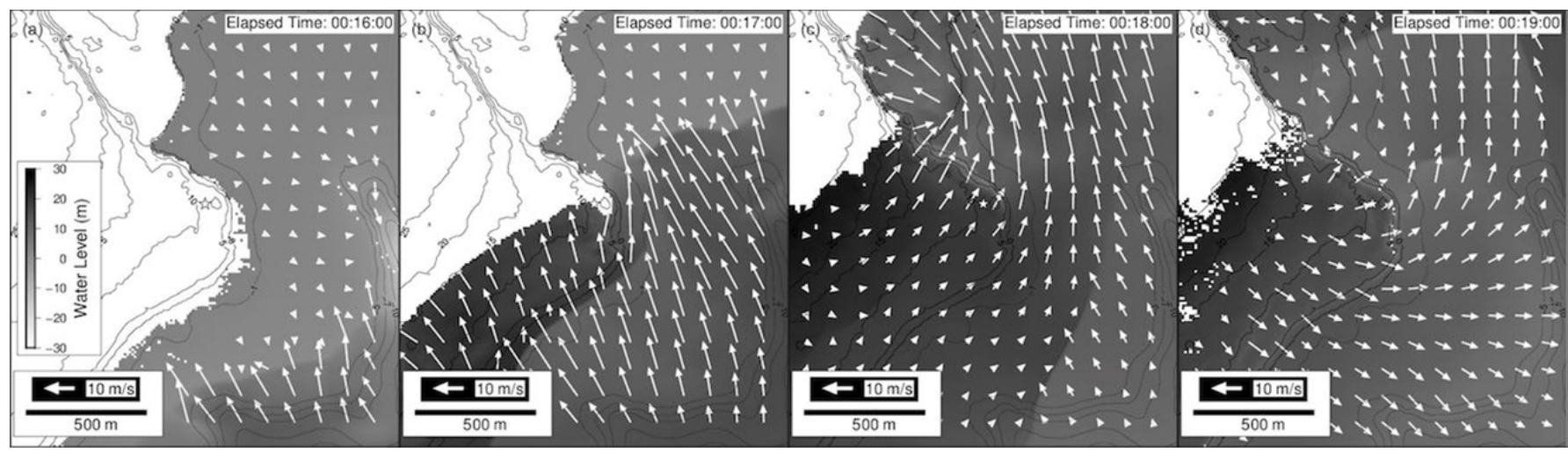

Figure 6. Snap-shots of numerical results for inundation of NK6 model. Each snap shows the wave height and current direction of (a) 16, (b) 17, (c) 18, and (d) 19 minutes after the tsunami generation.

fault of the MY model. We determined the NK4 model $(86.7 \%$ accuracy) and MY4 model ( $82.2 \%$ accuracy) as the benchmark tsunami of each model, respectively. Actually, the MY5 model can also give the same accuracy as the MY4 model. However, the tsunami generated by the MY5 model is too strong and thus the TU boulder was displaced from the present position by the latest event (i.e. the 1771 event). This is not consistent with the historical and geological evidence that suggest the TU boulder was located in its present location before the 1771 event and was not moved by the 1771 event (e.g., Kawana and Nakata, 1994; Goto et al., 2010). In contrast, the MY4 model moved the boulder less than $50 \mathrm{~m}$, which is within the range of uncertainty for this calculation. Therefore, we adopt the MY4 model as the benchmark tsunami.

\section{Boulder transport}

For NK models, six cases satisfied the constraint conditions (see Geological setting): (1) NK2 (first tsunami event) + NK6 (second tsunami event) models (Fig. 7a), (2) NK4 + NK6 models, (3) NK5 + NK6 models, (4) NK6 + NK6 models, (5) NK7 + NK5 models (Fig. 7b), and (6) NK7 + NK6 models. Considering that NK4 is the benchmark tsunami equivalent to the 1771 Meiwa tsunami, these results indicate that the second tsunami event was larger than the benchmark tsunami to move the boulder to its present position, but that the first tsunami can be either smaller or larger than the benchmark.

For MY models, six cases satisfied the constraint conditions: (1) MY4 + MY5 models, (2) MY5 + MY4 models, (3) MY6 + MY4 models, (4) MY6 + MY5 models, (5) MY7 + MY4 models, and (6) MY7 + MY5 models. Considering that MY4 model is the benchmark tsunami equivalent to the 1771 Meiwa tsunami, these results indicate that both the first and second tsunamis were equivalent to or larger than the benchmark tsunami.

\section{Discussion}

\section{Potential occurrence of paleo-tsunami larger than the 1771 event}

As summarized in Geological setting, geological evidence suggests that (1) the TU boulder emerged above the lowest sea level because of a tsunami occurring at around 321 B.C.-A.D. 140; that (2) it was moved (or rotated) again by a tsunami occurring after that event but before 1771, reaching its present position; and (3) it was not moved by the 1771 Meiwa tsunami.

Many cases satisfy constraint condition (1). In fact, as Table 4 shows, the tsunami size of the first event can be either smaller or larger than the benchmark tsunami (equivalent to the 1771 Meiwa tsunami), although the MY1 model and MY2 model can be excluded because no boulder would be able to emerge above sea level in these cases. Therefore, we infer that at least the second tsunami was equivalent to or larger than the benchmark tsunami (Table 4), irrespective of its original position that was changed somewhere by the first tsunami event.

According to Yamamoto et al. (2008), a sandy tsunami deposit was reported on the eastern coast of the Ishigaki Island. Its age was estimated after A.D. 1200, but before A.D. 1771. Kitamura et al. (2014) also suggested the potential occurrence of the tsunami, which was sufficiently large to leave sandy deposits at $8 \mathrm{~m}$ in elevation, in A.D. 1210-1450. These results might be compatible with the tsunami event

Table 4. Numerical results for boulder transport. $O$ signifies that at least one boulder stopped within the $50 \mathrm{~m}$ radius circle, $x$ means that no boulder stopped within the circle. Therefore we did not need to simulate the transport because the result will be expected.

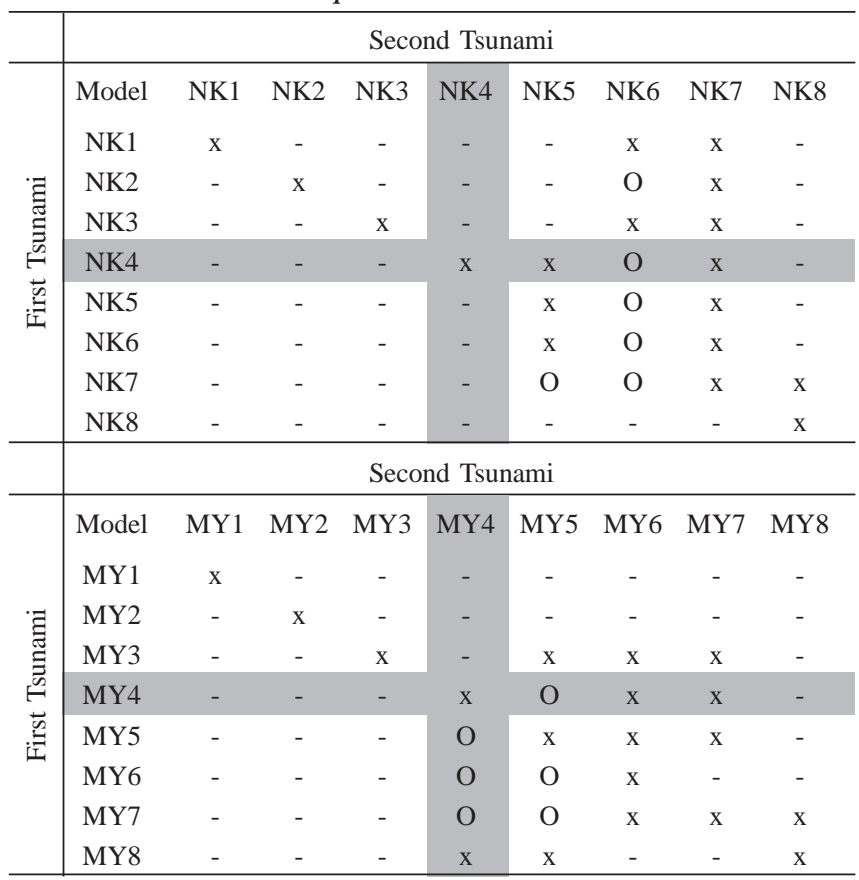



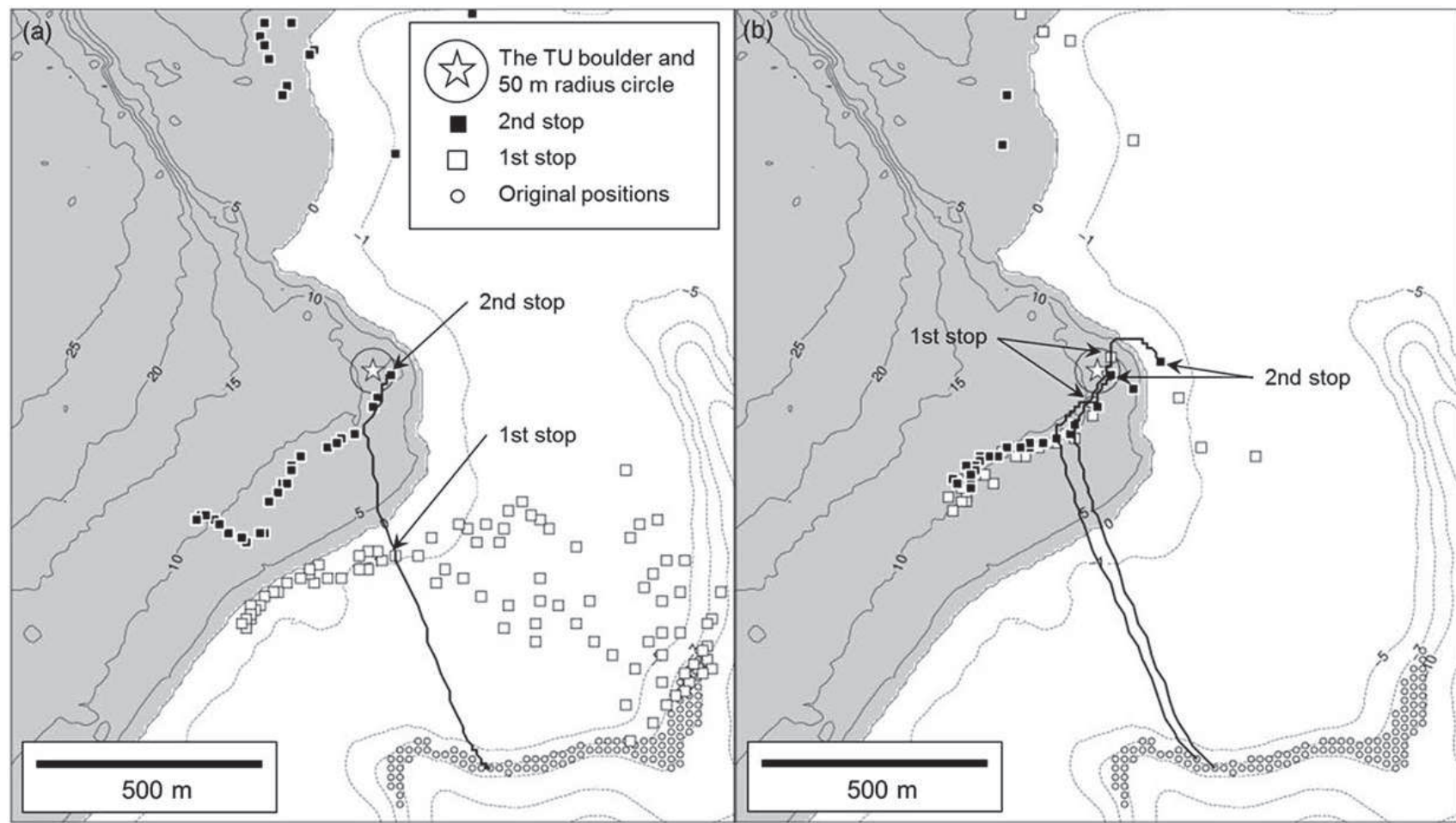

Figure 7. Numerical results for boulder transport by (a) NK2 + NK6 models and (b) NK7 + NK5 models.

on A.D. $1400 \pm 100$, as estimated by Araoka et al. (2013). Although additional careful research is required, our results support the potential occurrence at around this age of a tsunami that could have been larger than the 1771 Meiwa tsunami at the southern coast of the Ishigaki Island.

\section{Tsunami boulders as useful evidence to evaluate paleo-tsunami size}

As demonstrated in this study, tsunami boulders are extremely useful to evaluate the local size of paleo-tsunamis based on numerical modeling, even if it is a single isolated boulder. However, the estimation accuracy is strongly dependent on the available geological evidence.

We assumed that two tsunami events were sufficiently large to move the TU boulder based on Sato et al. (2013). However, Araoka et al. (2013) reported occurrence of seven tsunami events after 250 B.C. but before A.D. 1771, which in turn suggests that five tsunami events should have been small enough not to move (or rotate) the TU boulder. If we had no rotation history based on the paleo-magnetic information, then many combinations of tsunami sizes could be considered given the seven tsunami events. Even in that case, it would be possible to infer that at least one tsunami event before 1771 was equivalent to or larger than the benchmark tsunami and would move the TU boulder to its present position.

Moreover, it is noteworthy that the tsunami boulders in the Ishigaki Island were well studied and that paleo-tsunami recurrence was estimated (e.g., Araoka et al., 2013). However, in other areas of the world, it is not always possible to ascertain paleo-tsunami recurrence as we did at the Ishigaki Island. In fact, depositional ages of boulders are usually difficult to estimate if the boulders do not consist of bioclastic materials such as corals. Even in such cases, it seems possible to estimate the size of the paleo-tsunami which deposited the boulder at its present position. This is the fundamental idea underlying reconstruction of the tsunami size based on inverse modeling (e.g., Nandasena et al., 2011; Nott, 1997, 2003), but flow depth estimation by inverse modeling is not straightforward (e.g., Morton et al., 2006). Instead, forward modeling of boulder transport might useful to estimate the tsunami flow depth better at the boulder's position or to estimate offshore wave properties (Goto et al., 2014).

Further development of the method to elucidate the rotation history of boulders and numerical modeling is expected to be extremely useful for tsunami risk assessment in areas throughout the world where many coastal boulders are deposited.

\section{Conclusions}

Estimation of the paleo-tsunami size according to numerical modeling of boulder transport was tested in this study. We used only a single large coralline boulder in the Ishigaki Island and explored sizes of repeated paleo-tsunamis during the past 2400 years. Boulder transport by tsunamis of various sizes was simulated. Several combinations of tsunami sizes satisfying the geological conditions were obtained. Results suggest that at least one large tsunami equivalent to or larger than the 1771 Meiwa tsunami struck the area before 1771. Although the accuracy of this method depends greatly on the available geological evidence, we infer that numerical modeling of boulder transport will have great value for evaluation of the local tsunami size, which is important for local tsunami risk assessment.

\section{Acknowledgements}

This research was supported by Grants-in-Aid from the Japanese Ministry of Education, Culture, Sports, Science, and Technology to Goto (23684041) and a Grant-in-Aids from the Japan Society for the Promotion of Science $(22241042,26242033)$ and from IRIDeS, 
Tohoku University to Imamura. We thank D. Sugawara, C. Hongo and D. Araoka for their kind advice related to field surveys and numerical modeling. We also thank S. Fujino and Y. Ogawa for their valuable suggestions and comments.

\section{References}

Araoka, D., Yokoyama, Y., Suzuki, A., Goto, K., Miyagi, K., Miyazawa, K., Matsuzaki, H., and Kawahata, H., 2013, Tsunami recurrence revealed by Porites coral boulders in the southern Ryukyu Islands, Japan, Geology: v. 41, pp. 919-922.

Atwater, B.F., Musumi-Rokkaku, S., Satake, K., Tsuji, Y., Ueda, K., and Yamaguchi, D.K., 2005, The Orphan Tsunami of 1700 Japanese Clues to a Parent Earthquake in North America: U.S Geological Survey Professional Paper,v. 1707, p. 133.

Cisternas, M., Atwater, B.F., Torrejón, F., Sawai, Y., Machuca, G., Lagos, M., Eipert, A., Youlton, C., Salgado, I., Kamataki, T., Shishikura, M., Rajendran, C.P., Malik, J.K., Rizal, Y., and Husni, M., 2005, Predecessors to the giant 1960 Chile earthquake: Nature, v. 437, pp. 404-407.

Clague, J.J., Bobrowsky, P.T., and Hutchinson, I., 2000, A review of geological records of large tsunamis at Vancouver Island, British Columbia, and implications for hazard: Quaternary Science Reviews, v. 19, pp. 849863.

Dawson, S., and Shi, S., 2000, Tsunami Deposits: Pure and Applied Geophysics, v. 157, pp. 875-897.

Etienne, S., Buckley, M., Paris, P., Nandasena, N.A.K., Clark, K., Strotz, L., Chague-Goff, C., Goff, J., and Richmond, R., 2011, The use of boulders for characterising past tsunamis: lessons from the 2004 Indian Ocean and 2009 South Pacific tsunamis: Earth-Science Reviews, v. 107, pp. 76-90.

Frohlich, C., Hornbach, M.J., Taylor, F.W., Shen, C.-C., Moala, A., Morton, A.E., and Kruger, J., 2009, Huge erratic boulders in Tonga deposited by a prehistoric tsunami: Geology, v. 37, pp. 131-134.

Gelfenbaum, G., and Jaffe, B., 2003, Erosion and Sedimentation from the 17 July, 1998 Papua New Guinea Tsunami: Pure and Applied Geophysics, v. 160 , pp. $1696-1999$.

Goff, J., Chagué-Goff, C., Dominey-Howes, D., McAdoo, B., Cronin, S., Bonté-Grapetin, M., Nichol, S., Horrocks, M., Cisternas, M., Lamarche, G., Pelletier, B., Jaffe, B., and Dudley, W., 2010, Palaeotsunamis in the Pacific Islands: Earth-Science Reviews, v. 107, pp. 141-146.

Goff, J., and Chagué-Goff, C., 2012, A review of palaeo-tsunamis for the Christchurch region, New Zealand: Quaternary Science Reviews, v. 57, pp. 136-156.

Goto, K., Kawana, T., and Imamura, F., 2010a, Historical and geological evidence of boulders deposited by tsunamis, southern Ryukyu Islands, Japan: Earth-Science Reviews, v. 102, pp. 77-99.

Goto, K., Okada, K., and Imamura, F., 2010b, Numerical analysis of boulder transport by the 2004 Indian Ocean tsunami at Pakarang Cape, Thailand: Marine Geology, v. 268, pp. 97-105.

Goto, K., Miyagi, K., Kawana, T., Takahashi, J., and Imamura, F., 2011, Emplacement and movement of boulders by known storm waves - Field evidence from the Okinawa Islands, Japan: Marine Geology, v. 283, pp. 66-78.

Goto, K., Miyagi, K., Imamura, F., 2013, Localized tsunamigenic earthquakes inferred from preferential distribution of coastal boulders on the Ryukyu Islands, Japan: Geology, v. 41, pp. 1139-1142.

Goto, K., Hashimoto, K., Sugawara, D., Yanagisawa, H., and Abe, T, 2014, Spatial thickness variability of the 2011 Tohoku-oki tsunami deposits along the coastline of Sendai Bay: Marine Geology, in press.

Imamura, F., Yoshida, I., and Moore, A., 2001, Numerical study of the 1771 Meiwa tsunami at Ishigaki Island, Okinawa and the movement of the tsunami stones: Proceedings of Coastal Engineering, JSCE, v. 48, pp. 346-350.

Imamura, F., Goto, K., and Ohkubo, S., 2008, A numerical model for the transport of a boulder by tsunami: Journal of Geophysical Research Ocean, v. 113, C01008.

Iryu, Y., Nakamori, T., Matsuda, S., and Abe, O., 1995, Distribution of marine organisms and its geological significance in the modern reef complex of the Ryukyu Islands: Sedimentary Geology, v. 99, pp. 243-258.

Jankaew, K., Atwater, B., Sawai, Y., Choowong, M., Charoentitirat, T., Martin, M., and Prendergast, A., 2008, Medieval forewarning of the 2004 Indian Ocean tsunami in Thailand: Nature, v. 455, pp. 1228-1231.

Kawana, T., Nakata, K., and Omura, A., 1987, Age of the Fossil Coral from the "Tsunami-ufuishi" on Ohama of Ishigaki Island, the South Ryukyus, Japan: The Quaternary Research, v. 26, no, 2, pp. 155-158 (in Japanese with English title).

Kawana, T., and Nakata, K., 1994, Timing of Late Holocene tsunamis originated around the southern Ryukyu Islands, Japan, deduced from coralline tsunami deposits: Journal of Geography Japan, v. 103, p. 352376 (in Japanese with English abstract).

Kawana, T., 2006, Invasion of about 3400 cal BP large wave in the southeastern Okinawa Island and the surroundings, the Ryukyus, Japan, as deduced from coralline deposits: Bulletin of Department of Education University of Ryukyu, v. 68, pp. 265-271 (in Japanese with English title).

Kawana, T., 2008, Yuisa-Ishi on the reef crest off Chinen, Nanjo City, Okinawa Island: coralline block transported by the Ruth Typhoon in 1951: Bulletin of Faculty of Education, University of the Ryukyus, v. 72, 135-139 (in Japanese).

Kitamura, A., Ando, M., Tu, Y., Ohashi, Y., Nakamura, M., Miyagi, Y., Yokoyama, Y., Shiga, S., and Ikuta, R., 2014, Tsunami deposits in eastern coast area of Ishigaki Island, Japan (abs): Japan Geoscience Union Meeting 2014, MIS23-P11.

Koshimura, S., Mofjeld, H.O., Gonzalez, F.I., and Moore, A.L., 2002, Modeling the 1100 bppaleotsunami in Puget Sound, Washington: Geophysical Research Letters, v. 29, 1948.

MacInnes, B.T., Bourgeois, J., Pinegina, T.K., and Kravchunovskaya, E.A., 2009, Tsunami geo- morphology: Erosion and deposition from the 15 November 2006 Kuril Island tsunami: Geology, v. 37, pp. 995-998.

Miyazawa, K., Goto K., and Imamura, F., 2012, Re-evaluation of the 1771 Meiwa Tsunami source model, southern Ryukyu Islands, Japan: Submarine Mass Movements and Their Consequences, Advances in Natural and Technological Hazards Research, v. 31, pp. 497-506.

Morton, R.A., Richmond, B.M., Jaffe, B.E., Gelfenbaum, G., 2006, Reconnaissance investigation of Caribbean extreme wave deposits preliminary observations, interpretations, and research directions: OpenFile Report 2006-1293, USGS,p. 46.

Morton, R.A., Gelfenbaum, G., and Jaffe, B.E., 2007, Physical criteria for distinguishing sandy tsunami and storm deposits using modern examples: Sedimentary Geology, v. 200, pp. 184-207.

Nakamura, M., 2009, Fault model of the 1771 Yaeyama earthquake along the Ryukyu Trench estimated from the devastating tsunami: Geophys. Res. Lett., v. 36, L19307.

Nanayama, F., Satake,K., Furukawa,R.,Shimokawa,K., Atwater, B.F., Shigeno,K., and Yamaki,S., 2003, Unusually large earthquake inferred from tsunami deposits along the Kuril trench: Nature, v. 424, pp. 66066663.

Nandasena, N.A.K., Paris, R., and Tanaka, N., 2011, Reassessment of hydrodynamic equations: minimum flow velocity to initiate boulder transport by high energy events (storms, tsunamis): Marine Geology, v. 281, pp. 70-84.

Nandasena, N.A.K., and Tanaka, N., 2013, Boulder transport by high energy: numerical model-fitting experimental observations: Ocean Engineering, v. 57 , pp. 163-179.

Nott, J., 1997, Extremely high-energy wave deposits inside the Great Barrier Reef, Australia: determining the cause - tsunami or tropical cyclone: Marine Geology, v. 141, pp. 193-207.

Nott, J., 2003, Waves, coastal boulders and the importance of the pre-transport setting: Earth and Planetary Science Letters, v. 210, pp. 269-276.

Nott, J., and Bryant, E., 2003, Extreme marine inundations (tsunamis?) of coastal western Australia: Journal of Geology, v. 111, pp. 691-706. 
Petroff, C.M., Moore, A.L., and Árnason, H., 2001, Particle advection by turbulent bore - Orientation effects: ITS Proceedings, pp. 897-904.

Rhea, S., Tarr, A.C., Hayes, G., Villaseñor, A., and Benzl, H., 2010, Seismicity of the earth 1900-2007, Japan and vicinity. U.S.: Geological Survey Open-File Report, 2010-1083-D. pubs.usgs.gov/of/2010/1083/d/pdf/ OF10-1083D.pdf

Sato, T., Nakamura, N., Goto, K., Minoura, K., and Nagahama, H., 2013, Viscous remanent magnetization of individual boulders in Ishigaki Island and its application to estimate the paleotsunami histories (abs): AGU Fall meeting 2013, GP41A-1104.

Sato, T., Nakamura, N., Goto, K., Kumagai, Y., Nagahama, H., and Minoura, K., 2014, Paleomagnetism reveals the emplacement age of tsunamigenic: Geology, v. 42, pp. 603-606.

Sawai, Y., 2012, Evidence of past crustal movements and tsunamis recorded in geological deposits: AIST Today (International Edition), v. 45, pp. 10-11.

Scheffers, A., 2008. Tsunami boulder deposits, in Shiki, T., Tsuji, Y., Yamazaki,
T., Minoura, K. eds., Tsunamiites - Features and Implications: Berlin, Elsevier, pp. 299-318.

Sugawara, D., Goto, K., Imamura, F., Matsumoto, H., and Minoura, H., 2012, Assessing the magnitude of the 869 Jogan tsunami using sedimentary deposits: Prediction and consequence of the 2011 Tohoku-oki tsunami: Sedimentary Geology, v. 282, pp. 14-26.

Sugawara, D., Goto, K., and Jaffe, B.E., 2014, Numerical models of tsunami sediment transport - Current understanding and future directions: Marine Geology, v. 352, pp. 259-320.

Yamada, M., Fujino, S., Goto, K., in press, Deposition of sediments of diverse sizes by the 2011 Tohoku-oki tsunami at Miyako City, Japan: Marine Geology,doi: 10.1016/j.margeo.2014.05.019

Yamamoto, M., Hayata, T., and Kawana, T., 2008, Evidence of earthquake and tsunami in Ishigaki Island - Okinawa prefecture Karadake east shell mount / Karadake east tumuluses: Archaeology Quarterly, v. 106, pp. 91-92.

\section{Appendices}

\section{Appendix 1: Calibration method for measured radiocarbon age}

The measured radiocarbon age of the TU boulder (Tsunami ufu-ishi) by Kawana and Nakata (1994) was calibrated using the online CALIB program ver. 6.0 (http://calib.qub.ac.uk/calib/) and the MARINE09 calibration curve presented by Reimer et al. (2009), along with the local marine reservoir correction value for this region $(\Delta R=10 \pm 37$, Araoka et al., 2010).

\section{Appendix 2: Equations of numerical calculation}

With the tsunami inundation program, we conducted connection calculations from the first region to the fourth region. Linear long wave theory on a spherical earth (Equations (1)-(3)) was used for numerical calculations of tsunami propagation in region 1 (Fig. 3a, $300 \mathrm{~m}$ grid) with allowance made for the Coriolis force. Deformation attributable to faults and landslides was calculated according to the method explained by Mansinha and Smylie (1971).

$$
\begin{gathered}
\frac{\partial \eta}{\partial t}+\frac{1}{\partial R \cos \theta}\left[\frac{\partial M}{\partial \lambda}+\frac{\partial(N \cos \theta)}{\partial \theta}\right]=0 \\
\frac{\partial M}{\partial t}+\frac{g h}{R \cos \theta} \frac{\partial \eta}{\partial \lambda}=f N \\
\frac{\partial N}{\partial t}+\frac{g h}{R} \frac{\partial \eta}{\partial \theta}=-f M
\end{gathered}
$$

Therein, $\eta$ stands for the vertical displacement of water surface above the still water surface, $R$ signifies the radius of the earth, $\lambda$ and $\theta$ respectively represent longitude and latitude directions, $M$ and $N$ respectively denote discharge fluxes in the $\lambda$ and $\theta$ direction, $g$ represents the gravitational constant, $h$ stands for static depth of water, and $f=2 \omega \sin \theta$ denotes Coriolis's coefficient ( $\omega=$ the angular velocity of the earth rotation).

In region 2 (Fig. 3a, $100 \mathrm{~m}$ grid), region 3 (Fig. 3b, $50 \mathrm{~m}$ grid), and region 4 (Fig. 3c, $10 \mathrm{~m}$ grid), shallow-water theory on a Cartesian coordinate (Equations (4)-(6)) was used for tsunami propagation and run-up. The Staggered Leap-Frog scheme is used to solve equations numerically (Goto et al. 1997; Kotani et al., 1998).

$$
\begin{gathered}
\frac{\partial \eta}{\partial t}+\frac{\partial M}{\partial x}+\frac{\partial N}{\partial y}=0 \\
\frac{\partial \eta}{\partial t}+\frac{\partial}{\partial x}\left(\frac{M^{2}}{D}\right)+\frac{\partial}{\partial y}\left(\frac{M N}{D}\right)+g D \frac{\partial \eta}{\partial x}+\frac{g n^{2}}{D^{7 / 3}} M \sqrt{M^{2}+N^{2}}=0
\end{gathered}
$$




$$
\frac{\partial \eta}{\partial t}+\frac{\partial}{\partial x}\left(\frac{M N}{D}\right)+\frac{\partial}{\partial y}\left(\frac{N^{2}}{D}\right)+g D \frac{\partial \eta}{\partial y}+\frac{g n^{2}}{D^{7 / 3}} N \sqrt{M^{2}+N^{2}}=0
$$

Therein, $M$ and $N$ respectively denote discharge fluxes in the $x$ and $y$ directions, $D$ stands for the total water depth $(=h+\eta)$, and $n$ is the Manning's roughness coefficient.

In the boulder transport program, external forces, including those induced by the tsunami wave current, acting on the boulder are represented by the hydraulic force $F_{m}$, following the Morison formula, the friction force at the bottom $F_{b}$, and the component of the gravitational force $F_{g}$ along the slope (Noji et al., 1993).

$$
\begin{aligned}
& \rho_{s} V \ddot{x}=F_{m x}-F_{b x}-F_{g x} \\
& \rho_{s} V \ddot{y}=F_{m y}-F_{b y}-F_{g y}
\end{aligned}
$$

In those equations, $\rho_{s}$ stands for the boulder density, $V$ is the boulder volume. $F_{b x}$ and $F_{b y}$ respectively denote $x$ and $y$ components of $F_{b}$, and $F_{g x}$ and $F_{b y}$ respectively stand for the $x$ and $y$ components of $F_{g}, F_{m x}, F_{m y}, F_{b}$ and $F_{g}$ are determined as shown below.

$$
\begin{gathered}
F_{m x}=C_{D} \frac{1}{2} \rho_{f} A(u-\dot{x}) \sqrt{(u-\dot{x})^{2}+(u-\dot{y})^{2}}+C_{M} \rho_{f} V \dot{u}-\left(C_{M}-1\right) \rho_{f} V \ddot{x} \\
F_{m y}=C_{D} \frac{1}{2} \rho_{f} A(u-\dot{y}) \sqrt{(u-\dot{x})^{2}+(u-\dot{y})^{2}}+C_{M} \rho_{f} V \dot{v}-\left(C_{M}-1\right) \rho_{f} V \ddot{y} \\
F_{b}=\mu\left(\rho_{s}-\rho_{f}\right) V g \cos \theta \\
F_{g}=\left(\rho_{s}-\rho_{f}\right) V g \sin \theta
\end{gathered}
$$

Therein, $C_{D}$ and $C_{M}$ respectively represent coefficients of drag and mass, $\rho_{f}$ is the water density, $A$ is the projected area of the boulder against the current, $u$ and $v$ respectively denote the current velocity at the boulder position in the $x$ and $y$ direction, as obtained from tsunami inundation calculations in region 4. $\theta$ is the angle of the slope at the boulder position. We calculated the values of $V$ and $A$ by approaching the shape of the boulder as an ellipsoid body.

In the Boulder Transport by Tsunami model, the empirical variable coefficient of friction $\mu(t)$ is innovated (Imamura et al., 2008). They are assuming that the coefficient decreases as ground contact time become short when the boulder is transported by rolling or saltation related to the current velocity increase.

$$
\begin{gathered}
\mu=\frac{2.2}{\beta^{2}+2.2} \mu_{0} \\
\beta^{2}=\frac{\dot{x}^{2}+\dot{y}^{2}}{\left(1-\rho_{f} / \rho_{s}\right) g d}
\end{gathered}
$$

In those equations, $\beta$ denotes the degree of contact between the boulder and the floor, $\mu_{0}$ is the coefficient of dynamic friction during sliding, and $d$ is short-axis boulder length.

\section{References}

Araoka, D., Inoue, M., Suzuki, A., Yokoyama, Y., Edwards, R.L., Cheng, H., Matsuzaki, H., Kan, H., Shikazono, N., and Kawahata, H., 2010, Historic 1771 Meiwa tsunami confirmed by high-resolution U/Th dating of massive Porites coral boulders at The Ishigaki Island in the Ryukyus, Japan: Geochemistry Geophysics Geosystems, v. 11, no. 6, Q06014.

Goto, C., Ogawa, Y., Shuto, N., and Imamura, F., 1997, IUGG/IOC Time Project, Numerical Method of Tsunami Simulation with the LeapFrog Scheme:IOC Manuals and Guides, v. 35, p. 130.

Imamura, F., Goto, K., and Ohkubo, S., 2008, A numerical model for the transport of a boulder by tsunami: Journal of Geophysical Research Ocean, v. 113, C01008.

Kotani, M., Imamura, F., and Shuto, N., 1998. Tsunami run-up simulation and damage estimation by using GIS: Proceedings of Coastal Engineering JSCE, v. 45, pp. 356-360 (in Japanese).

Mansinha, L., and Staylie, D.E., 1971, The displacement fields of inclined faults: Bulletin ofthe Seismological Society of America, v. 61, pp. 1433-1440.

Noji, M., Imamura, F., and Shuto, N., 1993, Numerical simulation of movement of large rocks transported by tsunamis: Proceedings of IUGG/ IOC International Tsunami Symposium, pp. 189-197.

Reimer, P.J., and 27 others, 2009, INTCAL09 and MARINE09 radiocarbon age calibration curves, 0-50,000 years cal BP: Radiocarbon, v. 51, no. 4, pp. 1111-1150. 